\title{
Úlcera de Marjolin
}

\author{
Marjolin's Ulcer
}

Francisco MACEDO ${ }^{1}$, Sandra MACEDO², Filipa DRUMOND ${ }^{3}$, Miguel PESTANA ${ }^{4}$

Acta Med Port 2016 Jul-Aug;29(7-8):492-492 - http://dx.doi.org/10.20344/amp.6870

Palavras-chave: Carcinoma Espinocelular; Neoplasias da Pele; Úlcera Cutânea.

Keywords: Carcinoma, Squamous Cell; Skin Neoplasms; Skin Ulcer.

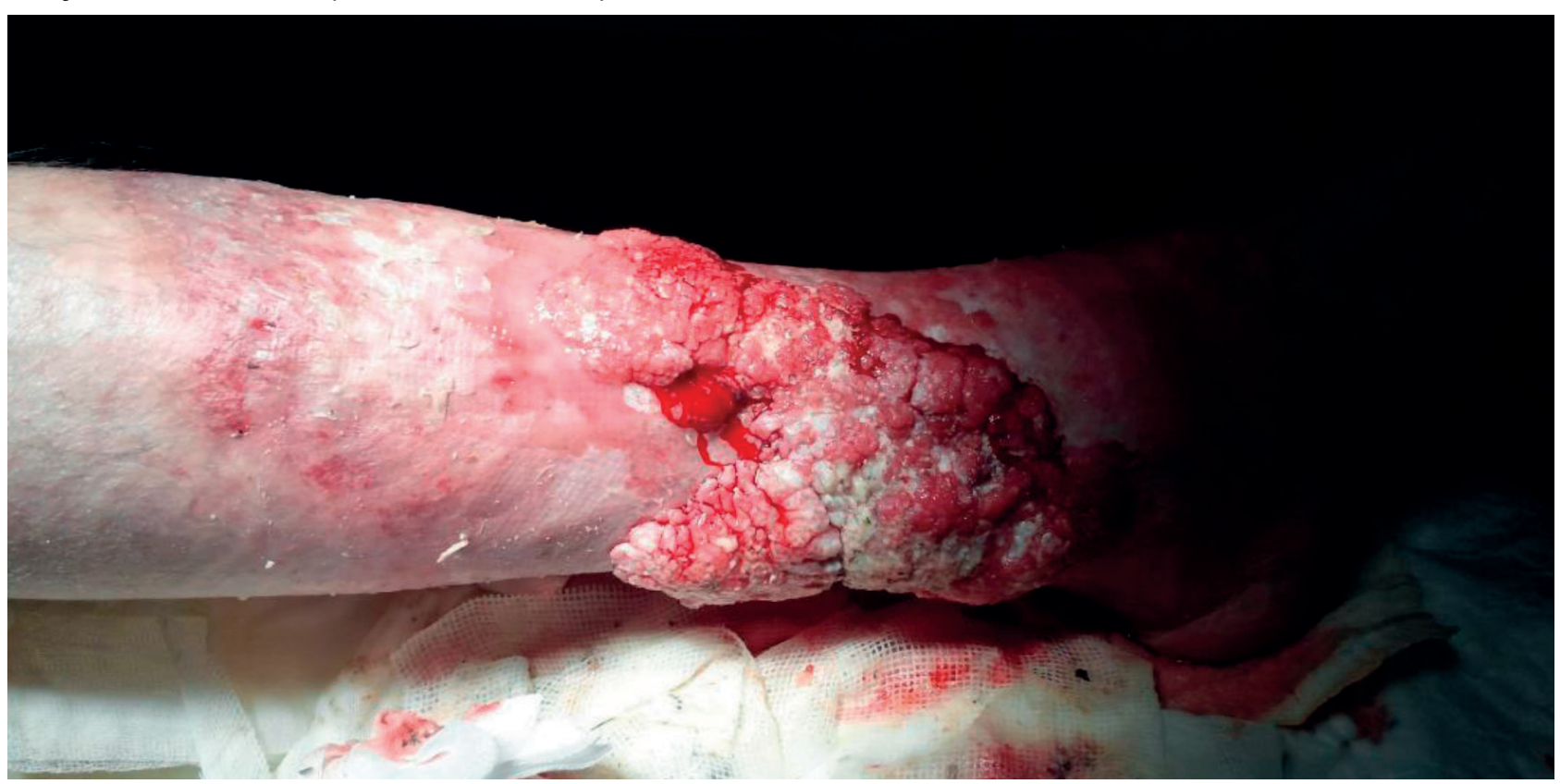

Figura 1 - Lesão exofítica na face externa da perna direita, com bordas elevadas, friáveis e consistência dura

A úlcera de Marjolin, refere-se à malignização de uma úlcera crónica, cicatrizes resultantes de queimadura ou sinus pilonidais. ${ }^{1,2,5} \mathrm{O}$ carcinoma espinocelular (CEC) encontrado na maior parte dos casos, localiza-se nas extremidades, particularmente nos membros inferiores. ${ }^{3}$

A latência até à transformação maligna é em média de três décadas. ${ }^{4}$

Homem, 65 anos, portador de úlcera venosa crónica com 15 anos de evolução. Apresenta dor intensa na perna e cheiro fétido, placa extensa de tecido vegetante sobre uma área de ulceração crónica com sinais infeciosos. Realizou 2 biópsias prévias ao episódio atual, que não confirmaram a suspeita de carcinoma. Realizou nova biópsia com diagnóstico de CEC. Após estadiamento da doença, o tratamento preconizado foi a remoção cirúrgica. A evolução clínica durante o internamento foi favorável.

Várias biópsias permitem diminuir os falso-negativos e facilitar a distinção entre hipertrofia pseudoepiteliomatosa e CEC. A cirurgia é o tratamento de eleição, pela maior taxa de cura e sobrevida. ${ }^{1-4}$

\section{REFERÊNCIAS}

1. Pavlovic S, Wiley E, Guzman G, Morris D, Braniecki M. Marjolin ulcer: an overlooked entity. Int Wound J. 2011;8:419-24.

2. Paredes F. A úlcera de Marjolin. Acta Med Port.1998;11:185-7.

3. Bauer T, David T, Rimareix F, Lortat-Jacob A. Marjolin's ulcer in chronic osteomyelitis: seven cases and a review of the literature. Rev Chir Orthop Reparatrice Appar Mot. 2007:93:63-71.

4. Hahn SB, Kim DJ, Jeon CH. Clinical study of Marjolin's ulcer. Yonsei Med J. 1990;31:234-41.

5. Tobin C, Sanger JR. Marjolin's ulcers: a case series and literature review. Wounds. 2014;26:248-54.

1. Centro de Saúde Dr. Rui Adriano de Freitas. Serviço de Saúde da Região Autónoma da Madeira. Funchal. Portugal.

2. Centro de Saúde do Bom Jesus. Serviço de Saúde da Região Autónoma da Madeira Funchal. Portugal.

3. Centro de Saúde Dr. Rui Adriano de Freitas. Serviço de Saúde da Região Autónoma da Madeira. Funchal. Portugal.

4. Serviço de Cirurgia Geral. Hospital Dr. Nélio Mendonça. Serviço de Saúde da Região Autónoma da Madeira. Funchal. Portugal.

$\triangle$ Autor correspondente: Francisco Macedo. franciscojsmacedo@gmail.com

Recebido: 02 de agosto de 2015 - Aceite: 09 de novembro de 2015 | Copyright @ Ordem dos Médicos 2016 